\title{
American Whiteness as Perpetual Madness: Don Quixote Through the Lens of Ibram X. Kendi's Stamped From The Beginning
}

\author{
Alice A. Oleson PhD \\ University of Dubuque, Dubuque, Iowa, U.S.A.
}

Doi: 10.19044/esj.2017.c1p14 URL:http://dx.doi.org/10.19044/esj.2017.c1p14

\begin{abstract}
In Stamped From The Beginning (2016), Ibram X. Kendi provides a typology of the ways in which segregationist racism, assimilationist racism, and anti-racism work in the U.S. through the lives of Cotton Mather, Thomas Jefferson, William Lloyd Garrison, W.E.B. Du Bois, and Angela Davis. Kendi's book thus offers several lived-in models for probing the reach of Whiteness, racism, and anti-racism in specific places and times rather than in the abstract. The academic abstraction of real-world problems is a danger that Vine Deloria, Jr. discussed as a part of his leadership within the American Indian Movement of the late 1960's and early 1970's. Deloria asked youth to avoid being "ego-fed by abstract theories and hence unwittingly manipulated" (1969:84). In the analysis to follow, I apply Kendi's typology of racist and anti-racist ideas to the novel Don Quixote as a practical work of anti-racism in the subject area of educational equity.
\end{abstract}

Keywords: Whiteness, educational equity, racism

\section{Introduction: Walking to educational equity the long way home}

In the spring of 2017, I carried Ibram X Kendi's 2016 National Book Award for Non-fiction winner, Stamped From the Beginning: The Definitive History of Racist Ideas in America, back to U.S. racism's home: Europe. Kendi's book is a justifiably heavy, blood-red tome, and as a fourth-generation Euro-American of German, Dutch, Norwegian, and Bohemian descent, I carried it heavily, too, promising myself that I would finish reading it on European soil during my month-long appointment as a visiting professor, teaching a classical social theory course (in English) to American studyabroad students in Alcala, Spain. Alcala is a cosmopolitan university city about fifteen miles outside of Madrid, and is a UNESCO World Heritage Site because it is the birthplace of Miguel de Cervantes Saavedra (1547-1616), author of Don Quixote. A magnificent statue of Cervantes with his feathered 
quill in hand adorns Alcala's vital Plaza de Cervantes, where transnational storks protecting permanent nests big as bathtubs reminded me daily of Spain's proximity to Africa.

Kendi opens by locating the genesis of contemporary U.S. racism in fifteenth-century Europe, and explains that U.S. racism's absolute cradle is carved in the rock of late medieval Spain and Portugal. He orients us to America with the Puritan's New England slavery circa 1630. This is roughly the same time in which Cervantes saw the Part One of Don Quixote published in 1605. As I began my teaching stint in one of Europe's oldest universities, founded in 1290, I felt the weight - the pull—of Don Quixote and Stamped From The Beginning in my traveling teacher's bag. Would I use my trip to Europe as an escape or would I engage in an analysis of what American Whiteness has shaped in me and what I might do to make myself less manipulated by it?

Kendi's final book chapter follows the life of American activist and intellectual, Angela Davis, and tells about a time when she was an undergraduate at Brandeis doing a "Junior Year Study-Abroad" program in France. One morning in September 1963, Davis picked up a French newspaper and read about the 16th-Street Baptist Church bombing in the United States. To her White peers' disbelief and ultimate inability to relate, Davis knew the four young girls who had been murdered by racist terrorists back home in Birmingham, Alabama. The slain children were her friends and neighbors. Later on in this chapter, Kendi quotes James Baldwin from London, reacting to Malcom X's murder on February 21, 1965: "'It is because of you,' he shouted at London reporters, 'the men who created this white supremacy, that this man is dead!'” (Kendi 2016:389).

\section{Kendi's typology of racist and anti-racist ideas}

Kendi's three-part typology affords any person practice in identifying segregationist racism, assimilationist racism, and anti-racism. A reader might then become better able to apply to his or her ethnic, social, spiritual, and political life what American Indian Movement (AIM) leader Vine Deloria Jr. defined as essential work for Native youth in America: "the arduous task of thinking out the implications of the status of Indian people in the modern world" (1969:83). Deloria argues that this cannot be achieved if Native youth follow dominant narratives about Native Peoples and colonization (past or present) as told to them by contemporary academics such as anthropologists. Decolonization of the mind is a necessary action of mutual responsibility for all people working toward a just society either as the oppressor or the oppressed (Trask 1993, Waziyatawin 2008). But this is so often not the case and truth-telling is left to those most victimized by racism. Denial persists as 
the ongoing work, shield, and weapon of racial supremacy (Churchill 1997, Mato Nunpa 2014).

No anti-racist supports denial. Kendi dedicates Stamped From The Beginning "To the lives they said didn't matter." On page one, he claims his work in the historical moment of "the shooting star of \#Black Lives Matter during America's stormiest nights" (2016:1). He invokes the names of Trayvon Martin, Rekia Boyd, Michael Brown, Freddie Gray, the Charleston 9, Sandra Bland, "heartbreaks that are a product of America's history of racist ideas as much as this history book of racist ideas is a product of these heartbreaks" (ibid.). Then, very simply on page two, Kendi gives readers the typology:

In 2016, the United States is celebrating its $240^{\text {th }}$ birthday. But even before Thomas Jefferson and the other founders declared independence, Americans were engaging in a polarizing debate over racial disparities, over why they exist and persist, and over why White Americans as a group were prospering more than Black Americans as a group. Historically, there have been three sides to this heated argument. A group we can call segregationists has blamed Black people themselves for the racial disparities. A group we can call antiracists has pointed to racial discrimination. A group we can call assimilationists has tried to argue for both, saying that Black people and racial discrimination were to blame for racial disparities (ibid.:2, emphasis in original).

Next, Kendi immediately applies the typology so that readers will grasp that this history book has feet planted equally in the past and present,

During the ongoing debate over police killings, these three sides to the argument have been on full display. Segregationists have been blaming the recklessly criminal behavior of the Black people who were killed by police officers. Michael Brown was a monstrous, threatening thief; therefore Darren Wilson had reason to fear and to kill him. Antiracists have been blaming the recklessly racist behavior of the police. The life of this dark-skinned eighteen-year-old did not matter to Darren Wilson. Assimilationists have tried to have it both ways. Both Wilson and Brown acted like irresponsible criminals (ibid., emphasis in original).

The rest of Stamped From The Beginning is divided into five equal sections, using the typology to examine the presence of segregationist racism, assimilationist racism, and anti-racism in the life and times of Cotton Mather, Thomas Jefferson, William Lloyd Garrison, W.E.B. Du Bois, and Angela Davis.

One of the learning opportunities given to me by Kendi is the gift of seeing that each one of us, regardless of our racial identities, holds the power/ability to further segregationist racism, assimilationist racism, and anti- 
racism. For example, Kendi argues that at key moments of their intellectual lives, monumental civil rights activists Douglass and $\mathrm{Du}$ Bois could be simultaneously their anti-racist best and their assimilationist worst (ibid.:199). Following the main tenants of critical race theory, American race equity educator, Glenn Singleton, argues that Whiteness is always in the room-in other words, that Whiteness structures every life and every institutional setting in America (2013). Each participant in his educational seminars is thus asked to specifically interrogate the ways in which Whiteness has invaded the "normalcy" of his or her thoughts, expectations, and interpretations. This questioning is foundational for the interruption of long-standing systems of racial power. Learning to practice Kendi's typology means using focused attention to see the typology not only in my life (as a representation of a disembodied kind of historical socialization), but also in the actual physical places that my body inhabits.

Indeed, Kendi's final pages attest to what I had been energized by in his opening pages - the importance of being an able thinker in one's locality. He writes,

Antiracist protesters have commonly rejected those racist ideas of what's wrong with Black people that are used to justify the plight of majority-Black spaces and the paucity of Black people in majorityWhite spaces. The most effective protests have been fiercely local; they are protests that have been started by antiracists focusing on their immediate surroundings: their blocks, neighborhoods, schools, colleges, jobs, and professions. These local protests have then become statewide protests, and statewide protests have then become national protests. (ibid.:510, emphasis added).

For any kind of locale-based activism to take hold, the past must always inform the present. For example, when Kendi introduces us to the young Thomas Jefferson in Chapter 7, he explains that Thomas was the son of a surveyor named Peter. In 1747, Peter "had been commissioned to certify that colonial America's westernmost point [the boundary-line between Virginia and North Carolina in the Blue Ridge Mountains] had not become like Jamaica's Blue Mountains, a haven for runaways" (ibid.:79). Describing the bondage-pastoralism of Jefferson's upbringing on twelve-hundred acres in Virginia's tobacco-growing Albemarle County, Kendi inserts the powerful but subtle statement, "In his home, no one around him saw anything wrong with the tyranny. Slavery was as customary as prisons are today" (ibid.:87).

Stamped From The Beginning consistently challenged me to staredown the mire of my racist hypnosis - which is not the inability to see the world for what it is, but the supremacist refusal to do so (Baldwin 1979). Milwaukee, Wisconsin is only a three hours' drive from my current residence, 
and is a place my family used to visit when I was a child to see the predatorprey exhibits at the Milwaukee County Zoo and also to attend Brewers' American League Baseball games. What I didn't know then is that our suburban family getaways meshed exactly with the U.S. War on Drugs, an initiative that has contributed to making Milwaukee County, by percentage, the world's largest incarcerator of Black and Native American men. University of Wisconsin-Milwaukee researcher, Professor John Pawasarat, analyzed over twenty years of Wisconsin's prison and employment data and

found that nearly 1 in 8 black men of working age in Milwaukee County had served some time in the state's correctional facilities. At 13 percent, the rate was about 3 percentage points above Oklahoma's - the state with the second highest rate of incarceration [in the U.S.] for black males. Gene Demby wrote about this same topic and noted that Wisconsin also has the highest rate of Native American men who are behind bars. 1 in 13 Indian men are incarcerated (Corley 2013: "Wisconsin Prisons Incarcerate Most Black Men In U.S.”).

As of this writing, The New York Times reports that the administration of New York Governor Andrew Cuomo "is awarding more than $\$ 7$ million in grants to a variety of colleges around the state to offer courses to prisoners" (McKinley, August 6, 2017: “Cuomo To Give Colleges \$7 Million For Courses In Prisons"). The article goes on to explain that,

[i]nmates in New York are already eligible for classes in about half of the state's 54 prisons, but they are largely funded by private sources. Mr. Cuomo, a Democrat in his second term who is said to have presidential ambitions, has been eager to expand educational programs in prisons, saying that only about 1,000 inmates currently take college-level classes. Under Mr. Cuomo's plan, that number would more than triple, with seven colleges and universities offering classes in 17 state prisons... [t]hose colleges include an Ivy League institution - Cornell Universitywhose faculty members will teach at four upstate prisons, as well as New York University, whose instructors will travel to Wallkill Correctional Facility, a medium-security prison in the Hudson Valley. Mercy College will serve Sing Sing, the famed maximum-security institution in Ossining, while teachers from Medaille College will instruct at Albion Correctional Facility. Two State University of New York community colleges-Mohawk Valley Community College and Jefferson Community College-have also been selected to participate (ibid.).

By having their eyes open to the world around them, UW-Milwaukee researchers Pawasarat and Demby - and perhaps many of the faculty who will be involved in Cuomo's initiative - may be exceptions to the rule. Time will tell if the fruits of these efforts will truly transform the lives of the people 
involved. In a scholarly article that sits close in tone to Kendi, Tulkin links the academic enterprise to the work of colonized minds by arguing that "[s]ocial scientists have been missionaries when they needed to be social change agents, and the result is that many programs have met with very minimal success" (1972:326).

When Angela Davis went to France in 1963, she learned about the murders of her friends and neighbors back home in America. In 1991, a boy with whom I attended Presbyterian Sunday school from grades one to five became one of the notorious cross-burners in my hometown of Dubuque, Iowa. I spent the freshman year of my undergraduate study at the University of Iowa that fall watching this young man and a few others interviewed in their fifteen-minutes of fame as America's freckle-faced racists of the hour on the nationally syndicated Phil Donohue Show. Today, I teach college students in my hometown. On my way back from Spain to resume this work, I met some fellow, White "Dubuquers" at the return gate of the Chicago O'Hare airport. It didn't take too much talking to ferret out our connections. I'd attended middle school with the man (but we didn't know one another) and among our shared set of acquaintances was one of the perpetrators of the 1991 crossburning. Like us, he would have been 44 years-old. "Did you know he just committed suicide?" the man asked me. I have a lot of reasons to practice Kendi's typology and to be honest, none of them are academic.

\section{Segregationist racism in Don Quixote}

I had not read Don Quixote prior to traveling to Alcala, Spain-but I had been accused of the self-catharsis of fighting windmills. However, the visceral experience of reading Kendi's history alongside Don Quixote in Spain was a powerful change agent for me. This is because it brutally underscored the deep entrenchment of Black dehumanization on the European soil that feeds the violence of American racism down to this day. Segregationist racism is any kind of idea that defines a targeted group as sub-human. We can see Europe's anti-Black, patriarchal racism in the relationship between Don Quixote and Sancho Panza, and then in the subsequent brutality that the latter exercises over even imagined African peoples. When Don Quixote was not cussing his peasant-squire, Sancho Panza, he often called him his "son." Sancho Panza endured these humiliations because Don Quixote promised to make Sancho Panza the governor of an island at the end of his successful adventures. In the following passage from the novel, we get an insight into Sancho's lusty fears and longing,

As for Sancho, who trudged long on foot, he felt again the aching grief for the loss of Dapple [his mule], but he bore it cheerfully, reflecting that his master was on the way to marry a princess, and so become at least King of 
Micomicon; though he was sorry to think that country was populated by negroes, and that when he became a ruler his vassals could be black. But then remembering a special remedy, he said to himself: 'What care I if my subjects be blacks?' What have I to do but ship them off to Spain, where I may sell them for ready money with which I may buy some title or office, on which I may live at ease all the days of my life? (1605, 2003:160).

I think about this excerpt as a map, as a story, basically, of my generational history as European migrant to America - and if Cervantes meant it as farce, as social satire, my socializations did not. We took land and lives that were not ours to take from the Native Peoples of North America and we bought and sold Black bodies, Black Lives, to "live at ease all the days of our life." I think of Kendi teaching me that the original word for "slave" was from the Bohemian "slav," and I learned that some of my pre-Minnesota, Bohemian ancestors would have then been the original slavers or enslaved people of Europe. I think of the rebuke I was socialized to carry when I fought with my three siblings growing up White in Dubuque, Iowa in the late 1970's and early 1980 's - No, I won't get that for you-I'm not your slave. In a recent American documentary film, I'm Not Your Negro (2017), Baldwin asks the White person to examine his or her heart for the reasons they need him to play an inferior role which he refuses.

Kendi also discusses the practice of Black Exhibits as examples of segregationist racism. He tells the stories of African American poet, Phillis Wheatley (1753-1784), and a woman named Sarah Baartman (1790-1815), who was sexually trafficked in European "freak shows" as the "Hottentot Venus." Both of these African women grew up in bondage and were forced to parade their minds and bodies before Euro-White patriarchal panels of judgement in the most dehumanizing ways possible. After Baartman's death in 1815, the famous European comparative anatomist, Georges Cuvier, removed, dissected, and preserved her genitals in what Kendi calls a "scientific rape" (2016:139). Cuvier concluded that Baartman's people, "[t]he Khoi people of South Africa...were more closely related to the ape than to the human" (ibid.). Baartman's skeleton, genitals, and brain were displayed in Paris until 1974. Nelson Mandela demanded the return of her remains when he took office in 1994. In 2002, France finally returned her remains to her homeland for burial (ibid.). Within Kendi's writing is an urgency to locate stories such as these in our own places. Growing up in Dubuque, Iowa, my father told me many times of the Mesquakie leader, Peosta. The White elders of my city had seen fit to display his bones as if he were an animal in a local, White mansion-turned-museum clear through to the 1980's. While reading Kendi in Spain, the Don Quixote trinkets and the life-sized statues in Alcala began to look to me like Black bodies for sale on those Spanish streets, those 
American ports, these American prisons, concentration camps (such as Fort Snelling, where Indigenous Dakota women, children, and men were forcemarched, detained, raped, starved, and otherwise murdered during the winter of 1863 in Minneapolis, Minnesota), and in the false recruitment propaganda of many American colleges today. In case I wanted to forget any of this, Kendi's writing allowed my eyes to see Sancho's continued colloquy in a new light,

No! I might as well go to sleep like a blockhead if I have not the gumption to sell thirty thousand Negroes in the twinkle of an eye! By God! I'll make them fly, little and big: even if they're blacker nor coal I'll turn them into white and yellow boys with the true ring out of them. Come on, all of you: I'm licking my fingers already (ibid., from "The quaint and delightful adventure that befell the curate and the barber in the same Sierra XVII).

As if speaking directly to Sancho Panza, and to all who follow in his Euro-American racist footsteps, Kendi quotes Malcolm X's 1964 statement to the United Nations,

Now you tell me how can the plight of everybody on this Earth reach the halls of the U.N... and you have twenty-two million African Americans whose churches are being bombed, whose little girls are being murdered, whose leaders are being shot down in broad daylight! And America still had the audacity or the nerve to stand up... with the blood dripping down his jaws like a bloody-jawed wolf (Malcolm X quoted in Kendi, pg. 384).

In the ongoing practice of Euro-American racism, there are those, too, who would turn families and societies and bodies and blood to coins and call themselves Christians, teachers, Saviors - and this is assimilationist racism.

\section{Assimilationist racism in Don Quixote}

In Alice Walker's fiction, the "mad dog is wise because it has lost its mind. Which is one of the most difficult things in the world to do" (1998:92). This is because within the wisdom of madness there is a lack of shame, "for what good would shame be to someone who might become at any moment that of which she is ashamed?" (ibid.:94). Don Quixote is perhaps the Western world's most celebrated mad man, and for most of the novel, he does lack shame, so convinced is he of his righteousness. It's the moments I think I'm most unlike Don Quixote that I run the danger of being most deluded (and racist). Through Kendi's analysis of William Lloyd Garrison, for example, I learned that abolitionism did not necessarily equate anti-racism - if it required Black people to change themselves in order to change White people's minds about African worth. Kendi reminds me that all of us can house the internalized colonialisms of uplift suasion, "the idea that White people could 
be persuaded away from their racist ideas if they saw Black people improving their behavior, uplifting themselves from their low station in American society" (ibid.:124). At his "maddest" moments, Don Quixote reminds me of the White Savior deluded into the disastrous belief in that "hand up." Oppressors can house "colorblind" racism - one that seeks to decrease the cognitive dissonance of racism by believing that racism is non-existent, dead, and/or that moving someone [of Color] to White middle-class status is noble and even God-blessed. This is the kind of assimilationist racism that I think many of Don Quixote's adventures can expose for fruitful, humanist reflection. Assimilationist racism has caused utter human destruction, such the generational trauma resulting from forced Native American boarding schools (from roughly the 1870's through the 1940's in the U.S.; see, for example, Lesiak 2007).

Very early on in his first set of knightly adventures, which Cervantes describes as "our imaginative hero's first sally from his home" $(1605,2003: 6)$, Don Quixote becomes an official knight after beseeching an innkeeper as follows,

and so I say unto you that the boon I have demanded and which out of your liberality have granted unto me, is that, tomorrow morning, you will dub me knight. This night I shall watch over my arms in the chapel of your castle and tomorrow, as I have said, you will fulfil my earnest desires, so that I may sally forth through the four parts of the world in quest of adventures on behalf of the distressed, as is the duty of knighthood and knights-errant who, like myself, are devoted to such achievements (ibid::13).

How like Whiteness this quote strikes me; mere humans granting themselves special status and privilege through the generations that abounds the world over. For if one who is steeped in Whiteness finds segregationist racism unpalatable, the assimilationist racism of the Peace Corps activist, the anthropologist, the abolitionist, the missionary, the social worker, the warden, the educator (etc.) await your service. I am in no way saying that people in these professions are unable to practice anti-racism; only that assimilationist racism is perhaps the easiest most profitable hand to play for institutional (and monetary) advancement.

How does one become a knight? As in the acquisition of Whiteness, it is not without violence. The innkeeper, as almost every person whom Don Quixote encounters, decides to have a little "sport," as he knights him,

The landlord did not relish the mad pranks of his guest, so he determined to make an end of them and give him the accursed order of chivalry before any further misfortune occurred...he went over to Don Quixote and ordered him to kneel: he then read in his manual [really an account of straw and 
barley supplied to his muleteers] as if he had been repeating some pious oration. In the midst of the prayer he raised his hand and gave him a good blow on the neck, and after that gave a royal thwack over the shoulders, all the time mumbling between his teeth as if he was praying (ibid.:16-17).

Surely there was no one moment in which I acquired Whiteness. However, the self-loathing that is required for the White person to try and maintain social and financial status by any means necessary demands a certain sense of worthlessness. To propagate the status of White, each generation must parent as they themselves have been parented-accepting heavy doses of humiliation and abuse, even by close loved ones, in the [hetero]gendered enterprise of acquiring (White) spouses and material possessions to mark one as a "good" person and in many cases, a Christian. The famous psychiatrist and intellectual, Franz Fanon, argues that colonizers project their own sickness with the self upon the colonized "other," who then may, in turn, predate upon his or her own psyche through the "White mask" of internalized racism (1952).

In the following scene, we find Don Quixote applying his newly acquired knighthood to a person whom he perceives as a lowly "other" in need of "help." Actions such as the one to follow are required as daily rituals of acquiescence, subjugation, and affirmation in a racist system that consistently "knights" White status and dehumanizes Bodies and Persons of Color as lack. If we have no helpless body, no Carlisle Indian boarding school student, no gangbanger, no damsel, and no underprepared "urban" student at our Primarily White Institution (PWI), we have no knight. For a knight exists only if a person whose life is perceived of by the racist as abject lack is in need of a clean-up. Immediately after leaving the inn, Don Quixote

had not traveled far when he thought he heard faint cries of someone in distress from a thicket on his right hand. No sooner had he heard them than he said: 'I render thanks to heaven for such a favor. Already I have an opportunity of performing the duty of my profession and of reaping the harvest of my good ambition. Those cries must surely come from some distressed man or woman who needs my protection.' Then turning his reins, he guided Rozinante [his horse] towards the place where the thought the cries came. A short distance within the wood he saw a mare tied to a holm-oak and to another a youth of about fifteen years of age naked from the waist upwards. It was he who was crying out, and not without reason, for a lusty countryman was flogging him with a leather strap, and every blow he accompanied with a word of warning and advice, saying: 'Keep your mouth shut and your eyes skinned.' The boy answered: 'I'll never do it again, master. By God's passion I promise in future to be more careful with your flock' (ibid.:19).

Here we have the necessary triad for assimilationist racism: the socially privileged insider who has acquired economic stability through generational wealth or current job (Don Quixote); the upper-class or upwardly 
mobile land-owner/power-holder (the countryman), and the exploited life and body of the out-casted human scapegoat (the fifteen year-old boy). Don Quixote shouts at the countryman, "Discourteous knight, it is a caitiff's deed to attack one who cannot defend himself. Get up on your horse and take your lance...I will show you that you have been acting a coward's part," (ibid.). Don Quixote then demands "justice" for the boy, "by the sun that shines on us I will pierce you through and through with this lance of mine. Pay him instantly and none of your denials. If not, by almighty God who rules us all I will annihilate you this very moment," (ibid.). The countryman unties the boy and promises Don Quixote that he will pay the youth his due. Thus, having received a feeling of justice rather than its actuality for the boy, Don Quixote exits the scene, off to his next self-fulfilling, identity-affirming adventure as a Knight on the side of the people.

It appears, too, that the assimilationist racist is the only one of the triad "fooled" into thinking that he or she has done some good. Everyone else knows how the system works and, indeed, Andrew knows the price he will come to pay for Don Quixote's braggadocio as do-gooder. Before Don Quixote exits the scene, Andrew beseeches of him, "the moment he gets me alone, he'll flay me like a Saint Bartholomew," (ibid.:20). To this, Don Quixote replies, "He will not do so...I have only to command and he will respect me and do my behest" (ibid.). In reality, the recipients of "White help" are usually much worse for the wear after that "help" is applied. Whether assimilationist racism is done with a tone of righteousness or guilt, neither is of any help to the person being systemically, inhumanly oppressed. It is a weak and cowardly way of fighting that is not fighting at all, but rather another one of the oppressor's drugs of escape from the crime that leaves the suffering person to encounter increased waves of psychological, economic, and bodily violence. We see this, too, in Don Quixote. As soon as Don Quixote is out of earshot, the countryman says to the boy, whom we now know as Andrew,

'Come here, my boy; I want to pay you what I owe you in accordance with the commands of that undoer of wrongs.'

'So you shall, I swear,' said Andrew, 'and you will be well advised to obey the orders of that good knight - may he live a thousand years; he surely is a courageous and good judge. By Saint Roch, if you don't pay me, he'll be back and he'll do what he threatened.'

'Faith and I'll swear too,' answered the countryman, 'and to show you my goodwill I'll increase the debt in order to increase the pay.' Catching the boy by the arm, he tied him again to the oak and gave him such a drubbing he left him for dead (ibid.:21). 
What the assimilationist racist fails (aka refuses) to perceive is that by using the object of his or her activism for basic psychic and material selfinterest, he is doing violence upon that body and life akin to that of the segregationist. Both the segregationist and assimilationist ultimately view the Body of Color as not only worthless but replaceable by another expendable, toiling body in a capitalist system. The segregationist uses the body for economic gain and psychological dominance. The assimilationist uses the body for psychic absolution and economic gain. Only the segregationist will admit this; however, the consequence is the same (see Kovel 1970, on the aggression of what he calls aversive racism). The perpetrators of assimilationist racism receive an illusion of good deeds. In this way they follow in the footsteps of Don Quixote, who takes on the special moniker Knight of the Rueful Figure to attest to all the "suffering" he endures for the so-called betterment of his fellow man.

Kendi defines anti-racism as basically three things:

1) Equity for all peoples now.

2) Humanity for all peoples now (i.e. all people, of all racial-ethnic groups possess the full range of human potential, good and bad).

3) Self-determination for all peoples now (this means voice-speaking for oneself and one's group), and not in some distant future when White people have finally come to accept that there is nothing inferior about Black people as a people.

It seems that this shift may never occur in America collectively, because Black as lack was already so entrenched in the European mind prior to colonization. A commentator to The Progressive's republishing of James Baldwin's December 1962 "A Letter to My Nephew" stated, “[m]ost of the [B]lack progress of the last fifty years is not 'black progress' at all but [W]hite people's progress at accepting black humanity" (JackAttack www.progressive .org/news 2014/12). Redefining the face of criminality in America from the stranglehold of my White socialization, James Baldwin wrote to his nephew in 1962 ,

I know what the world has done to my brother and how narrowly he has survived it and I know, which is much worse, and this is the crime of which I accuse my country and my countrymen and for which neither I nor time nor history will ever forgive them, that they have destroyed and are destroying hundreds of thousands of lives and do not know it and do not want to know it... but it is not permissible that the authors of devastation should also be innocent. It is the innocence which constitutes the crime (from "A Letter to My Nephew," The Progressive, December 1962). 
Baldwin tells his nephew about the price he is destined to pay for the innocence of Whites, which has been my (violently claimed) innocence. This is something, too, that Cervantes seemed to spotlight in Don Quixote's very first adventure as a knight, when he left a young man for dead and did not even know it. Don Quixote's adventures and his delusions were too precious to him to admit the cost paid by a mere youth for his imaginary dalliance. James Baldwin writes, "[p]lease try to remember that what they believe, as well as what they do and cause you to endure, does not testify to your inferiority, but to their inhumanity and fear" (ibid.).

What does White America fear? One thing that comes to mind is the truth, because as James Baldwin said, White reengagement with humanity requires the end of White innocence. This would necessitate truth, and a first truth with which to begin is one's name. Such knowledge represents a takingaccount of - and responsibility for-who one is in this centuries-long and continuing history of murder so that it can be ceased. This too, Cervantes seemed to know. Don Quixote's death is also his deliverance because eventually Don Quixote shows that he is capable of what American Whiteness has proven itself yet incapable of in its perpetual madness. At the end of the novel's Part Two, Don Quixote decides to claim his own name.

\section{Fool[ed] as noun not verb: Anti-racism in Don Quixote}

Who are the anti-racists, according to Kendi? He never hid his answer; he explains it right in the Prologue of Stamped From The Beginning. It is a truth so beautiful and complex and simple and impossible that it cannot be hidden. It belongs to everyone, but we must choose to seek it:

Racist ideas are ideas. Anyone can produce them or consume them, as Stamped from the Beginning's interracial cast of producers and consumers

show. Anyone-Whites, Latina/os, Blacks, Asians, Native Americansanyone can express the idea that Black people are inferior, that something is wrong with Black people. Anyone can believe both racist and antiracist ideas...[f]ooled by racist ideas, I did not fully realize that the only thing wrong

with Black people is that we think something is wrong with Black people. I did not fully realize that the only extraordinary thing about White people is that they think something is extraordinary about White people.

I am not saying that all individuals who happen to identify as Black (or White or Latina/o or Asian or Native American) are equal in all ways. I am saying that there is nothing wrong with Black people as a group, or with any other racial group. That is what it truly means to think as an antiracist: to think 
there is nothing wrong with Black people, to think that racial groups are equal (2016:11).

If there are parallels between the character of Don Quixote and the ways in which Kendi teaches us that the systemic and enduring racism of Whiteness works, then my reactions to Don Quixote's ending bear some witness. As much as I strive to be unlike Don Quixote in response to racism, murder, cultural and physical genocide, I must admit that everything that is described as perpetrated on the Jews in Exodus has also been perpetrated on Native Peoples and African peoples in America, and as a Euro-White, I have benefitted from that. It is mind-boggling then, that as a Euro-White, I also felt extremely sad when Don Quixote faced his deathbed and renounced all of his knight errantry. Most wrenchingly to my reading, in the last pages of the novel, Don Quixote renounces his very name - the name he had worked so hard for in Part One when he appointed himself Don Quixote, Knight of the Rueful Figure. This was because of all the physical pains he acquired including a broken jaw and some molars. In Part Two, Don Quixote took on his name Knight of the Lions after a caged and released lion that had been captured for a traveling circus refused to do battle with him. Yet here is what it sounded like when Don Quixote "changed,"

'[m]y dear friends, welcome the happy news! I am no longer Don Quixote of La Mancha, but Alonso Quixano, the man whom the world formerly called the Good owing to his virtuous life. I am now the sworn enemy of Amadis of Gaul, and his innumerable brood; I now abhor all profane stories of knight-errantry, for I know only too well through Heaven's mercy and through my own personal experience the great danger of reading them.'...'Those foolish tales,' replied Don Quixote, 'which up to now have been my bane may with Heaven's help turn to my advantage at my death. Dear friends, I feel that I am rapidly sinking; therefore let us put aside all jesting. I want a priest to receive my confession, and a notary to draw up my will. Therefore pray send for the notary while the priest hears my confession (Cervantes 1605, 2003:523-24).

I can see the similarities in Don Quixote's/Alonso Quixano's fictional life history and my very real historical Whiteness. In our first generations from Europe, some of my ancestors lost legs or life working for (not building) the railroads and alcoholism and depression stalk my family right along with our loyalty and self-sacrificing love. What I am saying is that our ascension to Whiteness has cost us for what it has cost our fellow humans. Yet, like the deluded Don Quixote, we deny. We abstract. We pull the wool of a wizard over our eyes and say that we fought for these names-for these Anglicized versions of our names. After the innocent blood was spilled, we attained our 
White, middle-class status. By the end of World War II and our usage of GI Bill benefits to [White] veterans, we achieved our paycheck to paycheck foothold, but perhaps most importantly to our survival, we became fully White. Like Don Quixote, we came to that part in the tale in which the caged lion would no longer fight with us, for if it did, we held the earthly, systemic power, the guns. We left behind the name Knight of the Rueful Figure, and like Don Quixote, became the smug but insecure Knight of the Lions instead. As Kendi argues,

Massachusetts authorities forbade interracial relationships, began taxing imported captives, and over Samuel Sewall's objections, rated Indians and Negroes with horses and hogs during a revision of the tax code. Virginia lawmakers made slave patrols compulsory for nonslaveholding Whites; these groups of White citizens were charged with policing slaves, enforcing discipline, and guarding routes of escape (Kendi 2016:68).

We were used - and because we chose not to admit that and to materially benefit from that, we "for mere meat barter[ed] [our] birthright in a mighty nation" (Du Bois 1904, 1973:45). We failed, and continue to fail, to grasp what Kendi and other anti-racists know: "If racism is eliminated, many White people in the top economic and political brackets fear that it would eliminate one of the most effective tools they have at their disposal to conquer and control and exploit not only non-Whites, but also both low-income and middle-income White people (2016:508).

Reclaiming my history and my names as an economically poor German, Bohemian, Norwegian-American woman has allowed me to see that the love that comes from American Whiteness is, in many ways, a love forged through coercion. There is a twisted, conditional component to White love that will love me only if. For example, if, as White woman, I am quiet enough, skinny enough, sexually desirable enough, pliant enough to gain a White man's protection. Is White love merely and supremely control? Perhaps. Because I cannot adequately put into words exactly what made Don Quixote stop being the tough buckle of his imagined knight errantry, but Kendi can. Kendi writes,

[h]istory is clear. Sacrifice, uplift, persuasion, and education have not eradicated, are not eradicating, and will not eradicate racist ideas, let alone racist policies. Power will never self-sacrifice away from its self-interest. Power cannot be persuaded away from its self-interest. Power cannot be educated away from its self-interest" (ibid.:508). 
As for me, trying to awake from the disastrous fiction, it's once again James Baldwin who lays bare the crisis of American Whiteness, this time through his analysis of Black English in America:

A language comes into existence by means of brutal necessity, and the rules of the language are dictated by what the language must convey. There was a moment, in time, and in this place, when my brother, or my mother, or my father, or my sister, had to convey to me, for example, the danger in which I was standing from the white man standing just behind me, and to convey this with a speed and in a language, that the white man could not possibly understand, and that, indeed, he cannot understand, until today. He cannot afford to understand it. This understanding would reveal to him too much about himself and smash that mirror before which he has been frozen for so long (1979, 1990:86-87, emphasis in original).

If an American White person survives the looking glass, though, what does that mean for the end of American racism? Surely, it does not mean that we, Whites, are good fighters yet. It means that we are delayed elders, delayed adults. It means we have so much work to do. It means to me that I must continue learning how to fight ably with, not for (and if for anyone, it must be for myself), because as Kendi argues, "altruism is wanted, not required" (2016:504) for the work of anti-racism. Furthermore,

\footnotetext{
[a]ntiracists should stop connecting selfishness to racism, and unselfishness to antiracism...Antiracists do not have to be selfless. Antiracists merely have to have intelligent self-interest, and to stop consuming the racist ideas that have engendered so much unintelligent self-interest over the years (ibid.).
}

From both Kendi and Cervantes I was reminded that birth, like death, requires pain to get us out to something new, something needed and longed for. This is something too, that my body taught me-that the land that is the body taught me - when I became a mother, twice. Believe me; that child was not going to be born with me folding up and pretending that I couldn't, though it was my daughter's own power that allowed her to be born whether I knew it or not that I belong to a Creator as an able person, through all my beauty and destruction.

\section{Conclusion: Educational equity in the here and now}

Midway through the final chapter of his book, Kendi brings us to the point in which Angela Davis reacted to Martin Luther King's murder, and in 
true heroic fashion, he still keeps teaching a reader about the typology as he does so:

King's death transformed countless doubly conscious activists into singly conscious antiracists, and Black Power suddenly grew into the largest antiracist mass mobilization since the post Civil-War period, when demands for land had been the main issue. The Godfather of Soul noticed Black America's brand new bag. With segregationists saying they should not be proud, with assimilationists saying they were not Black, James Brown began in August 1968 to lead the chant of millions: 'Say it Loud-I'm Black and I'm Proud,' a smash hit that topped the R \& B singles chart for six weeks. All these Black Power chants caused some African Americans to trash their racist color hierarchies within Blackness (the lighter, the better)...Antiracist Black Power compelled the controversial search for new standards, for Black perspectives, for Black people looking at themselves through their own eyes (ibid.:406).

The joy is not in the scholarly symmetry of Don Quixote and Stamped From The Beginning, but in hearing with fresh ears the voices of people defining themselves, through their own eyes, and thus battling racism head-on.

Tribal College Institutions (TCI's) and Historically Black Colleges and Universities (HBCU's) have practiced this kind of anti-racism for years and are vanguards of equitable education models to this moment. Diverse magazine reports that "[a] program at Miami University in Ohio offering language and cultural revitalization for members of the Miami Tribe of Oklahoma has led to graduation rates more than double the national average for Native American college students" (Elfman 2016:12). Student-led educational equity movements seem to get it right, too, and American society has seen a swell of them in recent years, including Being Black at Michigan (\#BBUM) and the "I, too, am Harvard" project. "I, too, am Harvard" project founder, Kimiko Matsuda-Lawrence, said that she started the self-defining movement after encountering the \#BBUM campaign: "[ $\mathrm{t}] \mathrm{o}$ hear our stories echoed in each other's voices, you feel your feelings are valid and legitimate" (Leonard 2014:22). The Crisis Magazine reports that,

[t]hese students turned to social media to document and disrupt existing narratives about post-raciality or diversity, to demand accountability. Beyond conversations, the students successfully leveraged the social media campaign and organizing on campus into action. While issues surrounding enrollment, housing, and curriculum remain, university officials ultimately agreed to increase funding for the BSU, to expand its recruitment of students of color, to create a scholarship for undocumented students, and to fund renovation of the campus multicultural center (ibid.:21). 
Campaigns similar to Harvard's are currently underway at "Ohio State University and Lehigh University, at UC Berkeley, Northwestern, SUNY New Paltz, University of Cape Town, University of Oxford, University of Sydney, McGill University and more than thirty other universities" (ibid::22).

Historically-aware, identity-centered resistances seem to happen in places where people decide to enact change right where they are. The people's very fight reclaims the sanctity of lives and land alike in these spaces. The Standing Rock Water Protectors and all of their allies who fought against the Dakota Access Pipeline (DAPL) in 2016 have breathed this knowledge anew for the world on American soil. For those people affecting change ably in a place: Kendi's typology can reinforce that work. For those Whites tired of fighting windmills, newly awake to fighting windmills, and wanting to say their names at the end of a wicked spell, cast by such an able enchanter as the Capitalist White: Kendi's typology can help any one of us navigate more ably toward anti-racism. Wherever we find ourselves and whenever we claim ourselves.

\section{References:}

1. Baldwin, James. "A Letter to My Nephew." The Progressive, December 1962. Reprinted December 2014 http://www.progressive.org/news

2. --“If Black English Isn't a Language, Then Tell Me What Is?" The New York Times Company, 1979. Reprinted in In Depth Essayists For Our Time, Karl Claus, Chris Anderson, and Rebecca Faery, editors. New York: Harcourt, Brace Jovanovich, 1990.

3. Cervantes Saavedra, Miguel de. Don Quixote, 1605. Republished and translated by Walter Starkie. New York: Signet Classics, 2003.

4. Corley, Cheryl. "Wisconsin Prisons Incarcerate Most Black Men in U.S."

5. http://www.npr.org/sections/codeswitch/2013/10/03/228733846/wisc onsin-prisons-incarcerate-most-black-men-in-u-s, 2013.

6. Churchill, Ward. A Little Matter Of Genocide: Holocaust and Denial in the Americas 1492 to the Present. San Francisco: City Lights Books, 1997.

7. Deloria, Vine Jr. Custer Died For Your Sins: An Indian Manifesto. University of Oklahoma Press, 1969, 1988.

8. Du Bois, W.E.B. "Credo" in The Independent, LVII (October 6, 1904), 787. Reprinted in Great Lives Observed: W.E.B. Du Bois, edited by William M. Tuttle, Jr. Englewood Cliffs, NJ: Prentice-Hall, 1973. 
9. Elfman, Lois. "Cultural Rejuvenation: Reclaiming heritage yields Native American student success at Miami University" in Diverse November 17, 2016.

10. Fanon, Frantz. Black Skin, White Masks. New York: Grove Press, 1952, 2008.

11. Kendi, Ibram X. Stamped From The Beginning: The Definitive History of Racist Ideas in America. New York: Nation Books, 2016.

12. Kovel, Joel. White Racism: A Psychohistory. New York: Pantheon Books, 1970.

13. Leonard, David J. "On Campuses Across The Country, Students Are \#Leaders Organizing And Insisting On Change" in thecrisismagazine.com Fall 2017.

14. Lesiak, Christine. In the White Man's Image: The Tragic Attempt to 'Civilize' Native Americans in the 1870's. PBS American Experience film documentary, 2007.

15. Mato Nunpa, Chris. "Historical Amnesia: The 'Hidden Genocide' and Destruction of the Indigenous Peoples of the United States" in Hidden Genocides: Power, Knowledge, Memory, edited by Alexander Laban Hinton, Thomas La Pointe, and Douglass Irvin-Erickson. Rutgers Press, 2014.

16. McKinley, Jesse. "Cuomo to Give Colleges $\$ 7$ Million for Courses in Prisons" https://www.nytimes.com/2017/08/06/nyregion/cuomo-togive-colleges-7-million-for-courses-in-prisons.html 2017.

17. Singleton, Glenn E. More Courageous Conversations About Race. Thousand Oaks, California: Corwin Press [SAGE], 2013.

18. Trask, Haunani-Kay. From A Native Daughter: Colonialism and Sovereignty in Hawai'i. Honolulu: University of Hawai'i Press, 1993.

19. Tulkin, Steven R. "An Analysis of the Concept of Cultural Deprivation." Developmental Psychology Vol. 6, No. 2, 326-339, 1972.

20. Walker, Alice. By The Light of My Father's Smile. New York: Random House, 1998.

21. Waziyatawin, Angela Wilson. What Does Justice Look Like?: The Struggle for Liberation in Dakota Homeland. St. Paul, Minnesota: Living Justice Press, 2008. 